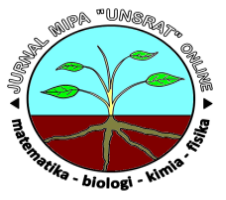

\title{
Skrining Fitokimia dan Uji Aktivitas Antioksidan dari Daun Nasi (Phrynium capitatum) dengan Metode DPPH (1,1-difenil-2-pikrilhidrazil)
}

\author{
Dwi Putra Wijayaa ${ }^{*}$, Jessy E. Paendonga, Jemmy Abidjulua
}

aJurusan Kimia, FMIPA, Unsrat, Manado

KATA KUNCI

Daun nasi

Phrynium capitatum

Fitokimia

Antioksidan

$\overline{\text { KEYWO R D S }}$

Daun nasi

Phrynium capitatum

Phytochemistry

Antioxidant
A B S T R A K

Telah dilakukan penelitian tentang skrining fitokimia dan uji aktivitas antioksidan dari daun nasi (Phrynium capitatum) dengan metode DPPH (1,1-difenil-2-pikrilhidrazil). Skrining fitokimia meliputi pengujian alkaloid, flavonoid, saponin, steroid, triterpenoid dan fenolik. Uji aktivitas antioksidan dilakukan dengan penambahan $2 \mathrm{~mL}$ larutan DPPH dengan $0,5 \mathrm{~mL}$ larutan ekstrak dengan konsentrasi masing-masing 1000, 750, 500 dan $250 \mu \mathrm{g} / \mathrm{mL}$. Data yang diproleh kemudian digunakan untuk menghitung nilai $\mathrm{IC}_{50}$ dari ekstrak etanol daun nasi. Hasil pengujian menunjukan bahwa ekstrak etanol daun nasi mengandung senyawa alkaloid, flavonoid, saponin, steroid dan fenolik. Ekstrak etanol daun nasi memiliki aktivitas antioksidan trrtinggi pada konsentrasi $1000 \mu \mathrm{g} / \mathrm{mL}$ sebesar $65,77 \%$ dan semakin menurun aktivitasnya dengan berkurangnya konsentrasi ekstrak, konsentrasi 750, 500 dan $250 \mu \mathrm{g} / \mathrm{mL}$ masing-masing sebesar 53,96 \%, 43,8 \% dan 19,58 \% dengan nilai IC 50 $_{5}$ pada konsentrasi $701,78 \mu \mathrm{g} / \mathrm{mL}$..

\begin{tabular}{l}
\hline A B S T R A C T \\
A research on phytochemicals screening and antioxidant activity test \\
of daun nasi (Phrynium capitatum) using DPPH (1,1-diphenyl-2- \\
picrylhydrazyl) method had been conducted. Test for alkaloids, flavonoids, \\
saponins, steroids, triterpenoids and phenolic were included in \\
phytochemical screening. Antioxidant activity was tested through the \\
addition of $2 \mathrm{~mL}$ DPPH solution into $0.5 \mathrm{~mL}$ of the extract having a \\
concentration of $1000,750,500$ and $250 \mu \mathrm{m} / \mathrm{mL}$ respectively. The data \\
obtained was used to calculate the $\mathrm{IC} 50$ value for the ethanol extract of \\
daun nasi. The results showed that the ethanol extract of daun nasi \\
contains alkaloids, flavonoids, saponins, steroids and phenolic. Ethanol \\
extract of daun nasi has the highest antioxidant activity of $65.77 \%$ at \\
concentration of $1000 \mu g / \mathrm{mL}$ Its activity decreased with decreasing \\
concentration of the extract, which were $53.96 \%, 43.8 \%$ and $19.58 \%$ at \\
concentration of 750,500 and $250 \mu g / m L$ respectively. IC 50 values was \\
found at a concentration of $701.78 \mu \mathrm{mL} / \mathrm{mL}$.
\end{tabular}

AVAILABLE ONLINE

25 Februari 2014

\section{Pendahuluan}

Berkembangnya pola hidup dalam kehidupan sehari-hari menyebabkan berbagai penyakit yang disebabkan oleh radikal bebas. Makanan yang digoreng, asap rokok, paparan sinar matahari berlebih, obat-obat tertentu, racun dan polusi udara merupakan beberapa sumber pembentuk senyawa radikal bebas. Radikal bebas (free radical) adalah suatu atom atau molekul yang mempunyai electron tidak berpasangan. Secara teoritis radikal bebas dapat terbentuk bila terjadi pemisahan ikatan kovalen, oleh karena sifatnya yang sangat reaktif dan gerakannya yang tidak beraturan, maka apabila

*Corresponding author: Jurusan Kimia FMIPA UNSRAT, Jl. Kampus Unsrat, Manado, Indonesia 95115; Email address: putra_rock45@rocketmail.com Published by FMIPA UNSRAT (2014) 
terjadi di dalam tubuh makhluk hidup akan menimbulkan kerusakan di berbagai bagian sel (Aruoma, 1994).

Masalah radikal bebas memunculkan penelitian untuk menangkal efek dari radikal bebas tersebut, salah satu yang banyak diteliti adalah penangkalan radikal bebas menggunakan senyawa antioksidan. Pada umumnya zat antioksidan yang banyak digunakan dalam bahan pangan adalah antioksidan sintetik, namun antioksidan ini sangat terbatas penggunaannnya, bahkan cenderung dihindari karena dapat bersifat karsinogenik (Barlow, 1989). Oleh karena itu penggunaan antioksidan alami merupakan alternatif yang lebih aman bagi kesehatan.

Daun nasi merupakan salah satu bahan alam yang banyak digunakan oleh masyarakat Sulawesi Utara. Daun nasi digunakan sebagai daun untuk membungkus nasi saat dimasak, dan juga diduga dapat menjadi obat bagi penderita penyakit gula, namun sampai saat ini belum ada penelitian mengenai bagaimana kandungan senyawa metabolit sekunder dan aktivitas antioksidan dari daun nasi. Hal inilah yang mendasari penulis merasa perlu untuk menguji kandungan fitokimia dan aktivitas antioksidan dari daun nasi.

\section{Metode \\ Tempat dan Waktu}

Penelitian ini telah dilaksanakan selama 2 bulan di Laboratorium Advance Jurusan Kimia Fakultas Matematika dan IImu Pengetahuan Alam Universitas Sam Ratulangi Manado.

\section{Alat dan Bahan}

Alat yang digunakan adalah sudip, ayakan 65 mesh, blender, timbangan analitik, aluminium foil, kertas saring Whatman no 42, spektrofotometer UVVis Genesys 20, tabung reaksi, labu ukur, oven, pipet tetes, evaporator, vortex, inkubator, erlenmeyer, rak tabung. Bahan yang digunakan adalah daun nasi, etanol $95 \%$, Iarutan $\mathrm{H}_{2} \mathrm{SO}_{4}$ pekat, pereaksi Mayer dan Dragendorff, kloroform, ammonia, $\mathrm{HCl}$ pekat, $\mathrm{HCl}$ I N, $\mathrm{FeCl}_{3} 1 \%$, serbuk $\mathrm{Mg}$, asam asetat anhidrida, 1,1-difenil-2-pikrilhidrazil (DPPH)

\section{Metode Penelitian}

\section{Preparasi Sampel}

Sampel yang diteliti adalah daun nasi yang diambil dari daerah Paniki kecamatan Mapanget barat. Sampel daun nasi dibersihkan dari pengotor lalu dikering anginkan selama 10 hari dan dihaluskan dengan menggunakan blender kemudian diayak dengan ayakan 65 mesh sampai diperoleh serbuk.

\section{Ekstraksi}

Ekstraksi sampel dilakukan secara maserasi, ditimbang sebanyak $50 \mathrm{~g}$ serbuk daun nasi, kemudian direndam dalam $500 \mathrm{~mL}$ etanol 95\% selama 5 hari lalu disaring dengan kertas saring
Whatman no 42 sehingga diperoleh filtrat. Filtrat yang diperoleh kemudian dievaporasi untuk mendapatkan ekstrak etanol. Ekstrak hasil evaporasi dimasukan ke dalam oven sampai menjadi ekstrak kental lalu didinginkan dalam desikator sebelum analisis lebih lanjut

\section{Uji Fitokimia (Harborne, 1996)}

\section{Pengujian Alkaloid}

Sebanyak $40 \mathrm{mg}$ ekstrak ditambahkan $2 \mathrm{~mL}$ kloroform dan $2 \mathrm{~mL}$ ammonia lalu disaring. Filtrat ditambahkan 3 sampai 5 tetes $\mathrm{H}_{2} \mathrm{SO}_{4}$ pekat lalu dikocok hingga terbentuk dua lapisan. Fraksi asam diambil, kemudian ditambahkan pereaksi Mayer dan Dragendorff masing-masing 4-5 tetes. Apabila terbentuk endapan menunjukkan bahwa sampel tersebut mengandung alkaloid, dengan pereaksi Mayer memberikan endapan berwarna putih, dan pereaksi Dragendorff memberikan endapan berwarna kuning-merah.

\section{Pengujian Fenolik}

Sebanyak 40 mg ekstrak ditambahkan 10 tetes $\mathrm{FeCl}_{3}$ 1\%. Ekstrak positif mengandung fenol apabila menghasilkan warna hijau, merah, ungu, biru atau hitam pekat.

\section{Pengujian Flavonoid}

Sebanyak 40 mg ekstrak ditambahkan dengan 100 $\mathrm{mL}$ air panas, didihkan selama 5 menit, kemudian disaring. Filtrat sebanyak $5 \mathrm{~mL}$ ditambahkan 0,05 $\mathrm{mg}$ serbuk $\mathrm{Mg}$ dan $1 \mathrm{~mL} \mathrm{HCl}$ pekat, kemudian dikocok kuat-kuat. Uji positif ditunjukkan dengan terbentuknya warna merah, kuning atau jingga.

\section{Pengujian Saponin}

Sebanyak $40 \mathrm{mg}$ ekstrak ditambahkan $10 \mathrm{~mL}$ air sambil dikocok selama 1 menit, lalu ditambahkan 2 tetes $\mathrm{HCl} 1 \mathrm{~N}$. Bila busa yang terbentuk tetap stabil \pm 7 menit, maka ekstrak positif mengandung saponin.

\section{Pengujian Steroid/Triterpenoid}

Sebanyak $40 \mathrm{mg}$ ekstrak ditambahkan $\mathrm{CH}_{3} \mathrm{COOH}$ glasial sebanyak 10 tetes dan 2 tetes $\mathrm{H}_{2} \mathrm{SO}_{4}$. Larutan dikocok perlahan dan dibiarkan selama beberapa menit. Steroid memberikan warna biru atau hijau, sedangkan triterpenoid memberikan warna merah atau ungu.

\section{Uji Aktivitas Antioksidan dengan Metode DPPH}

Sebanyak $2 \mathrm{~mL}$ larutan DPPH ditambahkan dengan $0,5 \mathrm{~mL}$ larutan ekstrak $250 \mu \mathrm{g} / \mathrm{mL}$, penambahan 2 $\mathrm{mL}$ larutan DPPH dilakukan pengulangan untuk setiap masing-masing larutan ekstrak 500, 750 dan 1000 mg/mL. Larutan dikocok sampai homogen dan dibiarkan selama 30 menit. Kemudian absorbansinya diukur terhadap metanol pada panjang gelombang $517 \mathrm{~nm}$ menggunakan spektrofotometer UV-Visible (Kresnawati \& Zainuddin, 2009). Nilai persentase inhibisi yang diwakili oleh nilai $\mathrm{IC}_{50}$ dihitung dengan rumus sebagai berikut : 
$\%$ Inhibisi $=\frac{(\text { A kontrol }- \text { A ekstrak })}{\text { A kontrol }} \times 100 \%$

Keterangan:

A kontrol $=$ Absorbansi tidak mengandung sample

A sampel $=$ Absorbansi ekstrak

Selanjutnya hasil perhitungan dimasukkan ke dalam persamaan regresi dengan konsentrasi ekstrak $(\mu \mathrm{g} / \mathrm{mL}$ ) sebagai absis (sumbu $X)$ dan nilai \% inhibisi antioksidan sebagai ordinatnya (sumbu Y). Nilai IC50 dihitung pada saat nilai \% inhibisi sebesar 50\% dengan menggunakan persamaan $Y=a x+b$.

\section{Hasil dan Pembahasan}

\subsection{Ekstraksi}

Berdasarkan ekstraksi sampel daun nasi yang dilakukan dengan teknik maserasi dengan etanol
95\% selama lima hari memberikan hasil seperti pada Tabel 1.

Tabel 1. Hasil Ekstraksi

\begin{tabular}{|c|c|c|c|}
\hline $\begin{array}{c}\text { Berat } \\
\text { serbuk } \\
\text { daun nasi } \\
(\mathrm{g})\end{array}$ & $\begin{array}{c}\text { Ekstrak } \\
\text { kental }(\mathrm{g})\end{array}$ & $\begin{array}{c}\text { Rendemen } \\
(\%)\end{array}$ & $\begin{array}{c}\text { Warna } \\
\text { ekstrak }\end{array}$ \\
\hline 50 & 5,3 & 10,06 & $\begin{array}{c}\text { Hijau } \\
\text { kehitaman }\end{array}$ \\
\hline
\end{tabular}

\subsection{Uji Fitokimia}

Pengujian fitokimia pada penelitian ini dilakukan menggunakan teknik pengujian menurut Harborne (1996). Hasil uji ini menunjukan bahwa daun nasi memiliki komponen aktif di dalamnya kecuali triterpenoid (Tabel 2).

Tabel 2. Hasil uji fitokimia pada ekstrak daun nasi

\begin{tabular}{|c|c|c|}
\hline Golongan senyawa & Hasil pengujian & Standard \\
\hline Alkaloid & + & Endapan putih (Mayer) \\
& + & Endapan kuning-merah ( Dragendorff) \\
\hline Fenolik & + & Warna merah, hijau, ungu, atau hitam pekat \\
\hline Flavonoid & + & Warna merah, kuning, atau jingga \\
\hline Steroid & + & Warna biru atau hijau \\
\hline Saponin & + & Terbentuk busa yang stabil \\
\hline Triterpenoid & - & Warna merah atau ungu \\
\hline
\end{tabular}

Keterangan : (+) terkandung dalam sampel; (-) tidak terkandung dalam sampel

\subsection{Uji Aktivitas Antioksidan}

Metode yang digunakan dalam pengujian aktivitas antioksidan dari daun nasi adalah metode dengan menggunakan larutan $\mathrm{DPPH}$, di mana 0,5 $\mathrm{mL}$ sampel ditambahkan dengan $2 \mathrm{~mL}$ larutan DPPH. Perubahan warna dari hasil pengujian aktivitas antioksidan dari daun nasi 1000, 750, 500 dan $250 \mu \mathrm{g} / \mathrm{mL}$ dapat dilihat pada Gambar 1.

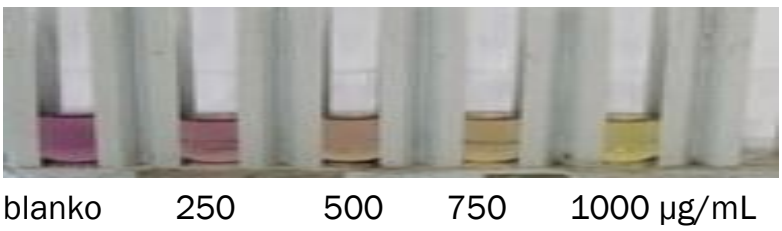

Gambar 1. Hasil pengujian warna pada penangkalan DPPH

Metode DPPH dipilih karena sederhana, mudah, cepat dan peka serta hanya memerlukan sedikit sampel (Molyneux, 2004). Mekanisme kerja dalam metode DPPH yaitu di mana senyawa antioksidan akan bereaksi dengan radikal DPPH melalui mekanisme donasi atom hidrogen dan menyebabkan terjadinya peluruhan warna DPPH dari warna ungu ke kuning yang kemudian diukur pada panjang gelombang $517 \mathrm{~nm}$ (Blois dalam Hanani et al., 2005). Struktur pada Gambar 2 adalah struktur di mana DPPH yang bersifat radikal kemudian berikatan dengan atom hidrogen yang berasal dari suatu antioksidan sehingga menjadi non radikal.

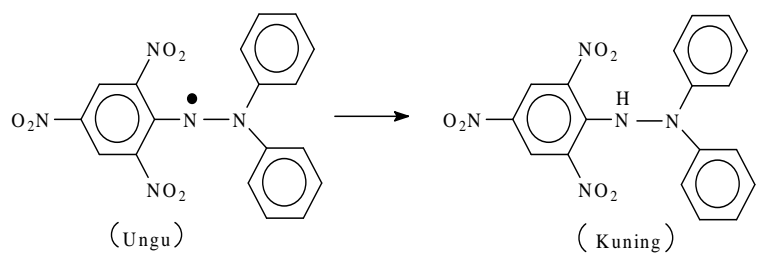

Gambar 2. Bentuk radikal DPPH menjadi nonradikal (Molyneux, 2004)

Berkurangnya intensitas warna larutan DPPH tersebut dapat menunjukkan bahwa terjadi reaksi antara atom hidrogen yang dilepas oleh bahan uji dengan molekul radikal DPPH sehingga terbentuk senyawa 1,1-difenil-2-pikrilhidrazin yang berwarna kuning. Berdasarkan hasil percobaan pada konsentrasi daun nasi $1000 \mathrm{\mu g} / \mathrm{mL}$ terlihat perubahan warna

yang jelas dari warna ungu menjadi warna kuning kemudian perubahan warna semakin melemah dari konsentrasi 750, 500 dan 250 $\mu \mathrm{g} / \mathrm{mL}$. Menurut Widyaningsih (2010) semakin besar konsentrasi bahan uji, warna kuning yang dihasilkan akan semakin kuat. 
Hasil dari perbandingan persen inhibisi dengan konsentrasi ekstrak menghasilkan persamaan garis $\mathrm{y}=0.059 \mathrm{x}+8.595$ dengan $\mathrm{R}^{2}=0.956$ dapat dilihat pada Gambar 3.

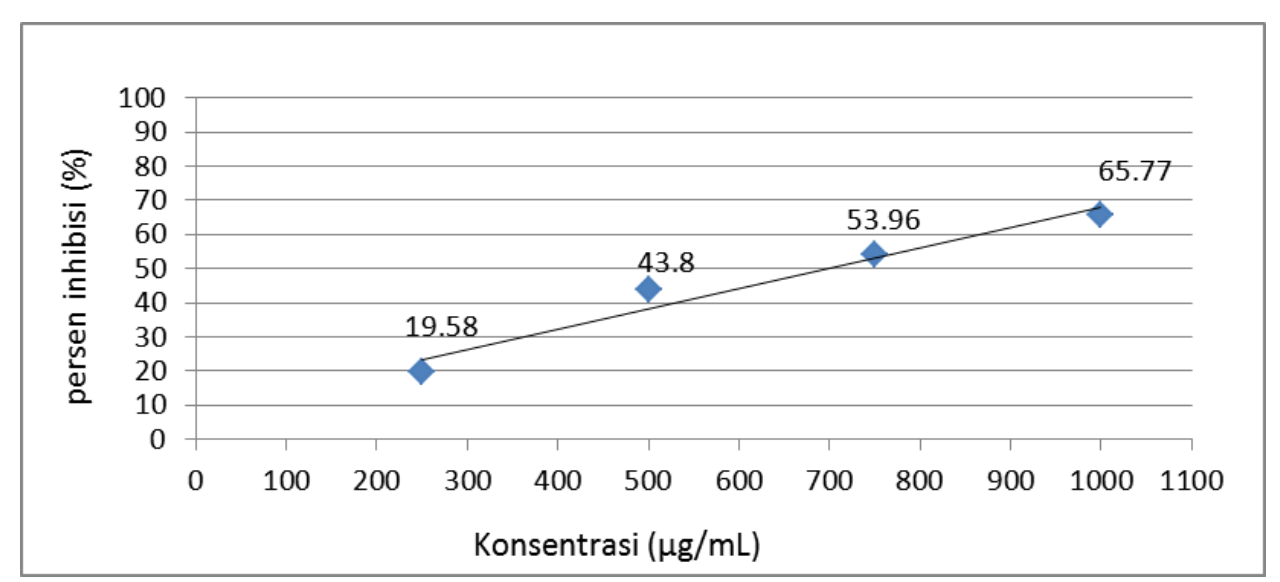

Gambar 3. Hasil pengukuran persen inhibisi ekstrak daun nasi terhadap DPPH

Berdasarkan data yang didapat semakin besar konsentrasi ekstrak maka semakin besar persen inhibisinya, persen inhibisi tertinggi terdapat pada konsentrasi $1000 \mu \mathrm{g} / \mathrm{mL}$ sebesar 65,77\% kemudian menurun bersamaan berkurangnya konsentrasi ekstrak. Berdasarkan dari hasil perhitungan $\mathrm{IC}_{50}$ menunjukkan bahwa daun nasi memiliki aktivitas antioksidan dengan nilai $\mathrm{IC}_{50}$ pada $701,78 \mu \mathrm{g} / \mathrm{mL}$. Harga $\mathrm{IC}_{50}$ berbanding terbalik denga aktivitas antioksidan, semakin besar harga $\mathrm{IC}_{50}$ maka aktivitas antioksidan semakin kecil.

\section{Kesimpulan}

Berdasarkan pengujian skrining fitokimia dan aktivitas antioksidan yang telah dilakukan maka dapat diambil kesimpulan bahwa komponen senyawa yang aktif yang terdapat pada daun nasi adalah alkaloid, flavonoid, saponin, steroid dan senyawa fenolik. Ekstrak etanol daun nasi memiliki aktivitas antioksidan tertinggi pada konsentrasi $1000 \mu \mathrm{g} / \mathrm{mL}$ sebesar 65,77 \% dan semakin menurun aktivitasnya dengan berkurangnya konsentrasi ekstrak yaitu pada konsentrasi 750 , 500 dan $250 \mu \mathrm{g} / \mathrm{mL}$ masing-masing sebesar 53,96 $\%$, 43,8 \% dan $19,58 \%$ dengan nilai $I_{50}$ pada konsentrasi $701,78 \mu \mathrm{g} / \mathrm{mL}$

\section{Daftar Pustaka}

Aifin, H., Anggraini, N., Handayani, D. \& Rasyid R. 2006. Standarisasi Ekstrak Etanol Daun Eugenia Cumini Merr. Journal of science technology. 11: 88-93.

Arum, Y. P., Supartono \& Sudarmin. 2012. Isolasi dan Uji Daya Antimikroba Ekstrak Daun Kersen (Muntingia calabura). Jurnal MIPA. 35: 165-174.

Aruoma, O. I. 1994. Free radicals and antioxidant strategies in sports. J Nutr Biochem. 5: 370-381.
Balasundram, N., Sundram, K. \& Samman, S. 2006. Phenolic Compounds in Plants and Agriindustrial by Products: Antioxidant Activity, Occurrence, and Potential Uses. Food Chem. 99: 191-203.

Barlow, S. M. 1989. Toxicological Aspect of Antioxidants Used As Food Additives. Food Chem. 49: 2774-2779.

Bjelakovic, G., Nikolova, D., Gluud, L.L., Simonetti, R.G. \& Gluud, C. 2007. Mortality in Randomized Trials of Antioxidant Supplements for Primary and Secondary Prevention: Systematic Review and Meta-Analysis. JAMA. 8: 842-857.

Boer, Y. 2000. Uji Aktivitas Antioksidan Ekstrak Kulit Buah Kandis (Garcinia parvifolia Miq), Jurnal Matematika dan IPA. 1: 26-33.

Cody, V. 1985. Flavonoid in Biology And Medicine II, Biochemical Celluler And Medicinal Properties. Liss Inc. New York.

Damayanthi, E., Kustiyah, L., Khalid, M. \& Farizal, H. 2010. Aktivitas Antioksidan Bekatul Lebih Tinggi Dari Pada Jus Tomat Dan Penurunan Aktivitas Antioksidan Serum Setelah Intervensi Minuman Kaya Antioksidan. Departeman Gizi Masyarakat, Fakultas Ekologi Manusia. IPB. Bogor.

Dayanti, R \& Suyatno. 2012. Aktivitas Antioksidan Ekstrak Metanol Bagian Batang tumbuhan Paku Nephrolepis radicans (Burm.) Kuhn. Journal of Chemistry. 1: 86-92.

Djamal, R. 1988. Tumbuhan Sebagai Sumber Bahan Obat. Pusat Penelitian. Universitas Negeri Andalas.

Gorog, S. D. S. \& Szasz, C. S. 1978. Analysis of Steroid Hormone Drugs. Elsevier and Co. New York.

Hanani, E., Mun'im, A. \& Sekarini, R. 2005. Identifikasi Senyawa Antioksidan dalam Spons Callyspongia sp dari Kepulauan Seribu. Majalah IImu Kefarmasian. 2: 127 - 133. 
Harborne, J. B. 1996. Metode Fitokimia. edisi kedua. ITB. Bandung.

Herbert, R. B. 1989. The Biosynthesis of Secondary Metabolism. Campman and Hall. New York.

Heyne, K. 1987. Tumbuhan Berguna Indonesia. Badan Litbang Departemen Kehutanan. Jakarta.

Ionita, P. 2003. Is DPPH Stable Free Radical a Good Scavenger For Oxygen Activem Species?. Journal of Chemistry. 59: 11-16.

Juniarti, Osmeli, D. \& Yuhernita. 2009. Kandungan Senyawa Kimia, Uji Toksisitas (Brine Shrimp Lethality Test) dan Antioksidan (1,1-Diphenyl-2Picrilhydrazyl) dari Ekstrak Daun Saga (Abrusprecatorius L.). Makara Sains.13: 50-54.

Kresnawaty, I. \& Zainuddin, A. 2009. Aktivitas Antioksidan dan Antibakteri dari Derivat Metil Ekstrak Etanol Daun Gambir (Uncaria gambir). Jurnal Littri. 15: 145 - 151.

Kumalaningsih, S. 2006. Antioksidan Alami. Cetakan Pertama. Trubus Agrisarana. Surabaya.

Lapornik, B., Prosek, M. \& Wondra, A. G. 2005. Comparison of Extracts Prepared From Plant by Products Using Different Solvents and Extraction Time. Journal Food Engineering. 71: 214-222.

Markham, K. R. 1988. Techniques of Flavonoids Identification, diterjemahkan oleh Kosasih Padmawinata. ITB. Bandung.

Marliana, S. D., Suryanti, V. \& Suyono. 2005. Skrining Fitokimia dan Analisis Kromatografi Lapis Tipis Komponen Kimia Buah Labu Siam (Sechium edule Jacq. Swartz.) dalam Ekstrak Etanol. Biofarmasi. 3 : 26-31.

Molyneux, P. 2004. The Use of The Stabil Free Radical Diphenylpicrilhydrazyl (DPPH) For Estimating Antioxidant Activity. Journal of science technology. 26: 211-219.
Naczk, M. \& Shahidi, F. 2006. Phenolics in Cereals, Fruits and Vegetables:Occurrence, Extraction and Analysis. Journal of Pharmaceutical and Biomedical Analysis. 41: 1523-1542.

Neuman, R. C. Jr. 2013. Organic Chemistry. University of California. Riverside.

Proctor, P. H. \& Reynolds, E. S. 1984. Free radicals and Disease in Man. Physiological Chemistry and Physics medical NMR. 16:175-95.

Robinson, T. 1991. The Organic Constituen of HigherPlants. $6^{\text {th }}$ Edition. Department of Biochemistry. University of Massachusetts.

Sembiring, B. Br., Ma'mun \& Ginting, E.I. 2006. Pengaruh Kehalusan Bahan dan Lama Ekstraksi Terhadap Mutu Ekstrak Temulawak (Curcuma xanthorriza Roxb). Bul. Littro. 17: 53-58.

Sholihah, Q. \& Widodo, M. A. 2008. Pembentukan Radikal Bebas Akibat Gangguan Ritme Sirkadian dan Paparan Debu Batubara. Jurnal Kesehatan Lingkungan. 4: 89 - 100.

Sunarni, T. 2005. Aktivitas Antioksidan Penangkap Radikal Bebas Beberapa Kecambah dari Biji Tanaman Familia Papilionaceae. Jurnal Farmasi Indonesia. 2: 53-6.

Tarigan, J. B., Zuhra, C. F \& Sihotang, H. 2008. Skrining Fitokimia Tumbuhan yang Digunakan Oleh Pedagang Jamu Gendong Untuk Merawat Kulit Wajah di Kecamatan Medan Baru. Jurnal Biologi Sumatera. 3: 1-6.

Widyaningsih, W. 2010. Uji Aktivitas Antioksidan Ekstrak Etanol Daun Dewa (Gynura procumbens) dengan Metode DPPH (1,1-difenil-2pikrilhidrazil). [Prosiding Seminar Nasional Kosmetika Alami].

Yuhernita \& Juniarti. 2011. Analisis Senyawa Metabolit Sekunder dari Ekstrak Metanol Daun Surian yang Berpotensi Sebagai Antioksidan. Makara Sains. 15: 48-52. 